\title{
MODERN MILITARY GEOGRAPHY
}

\section{Francis A. Galgano and Eugene J. Palka (eds)}

Routledge, New York

2011, 437 Pages

Appendices, figures, maps, tables, photographs

ISBN 978-0-415-87095-5

Modern Military Geography is a new text that explores the relationship between geography and military conflict. As such, it covers many different scenarios and operational theatres and brings perspective to the link between local topography, hydrographical settings, climate, coastal conditions and military operations. The text goes further by examining the influence of secondary factors, which include, biological, health and environmental issues on military operations. The unique interaction between physical conditions and the geopolitical realities of different geographical settings are well illustrated. This book is therefore an excellent addition to the fields of military geography and military history, as well as other related military disciplines.

Modern Military Geography consists of twenty-three chapters, written by fourteen authors from mainly the United States. All the authors are or have been professional military officers with extensive military operational experience and interests. The editors of the text, Lieutenant Colonel ret. Francis Galgano (associate professor) and Colonel Eugene Palka (professor), are both seasoned and internationally acclaimed researchers in the subject matter of the text. This is evident in the manner in which the text is organised to form a central theme throughout, as opposed to a number of loose essays.

Modern Military Geography is divided into three parts, namely the nature of military geography, case studies from history and the application of military geography. The first part, consisting of seven chapters, provides the background for the reader who might be new to the fields of geography and military geography, and

Scientia Militaria, South African Journal of Military Studies, Vol 40, Nr 1, 2012, pp. 144-145. doi: $10.5787 / 40-1-989$ explains the relationship between environmental issues and regional security or insecurity. This is followed by an analytical approach to the historical background, traditional subject matter, methodology and 
pedagogies of military geography.

The second part, consisting of eight chapters, presents the readers with classical historical case studies that clearly illustrate the link between warfare and geography. These include well-known and well-documented military operations from the American Civil War, the Anglo-Boer War, the Second World War, the Korean War, the Yugoslavia Civil War and the recent military operations of the United States military in Afghanistan and Iraq.

The third and final part, consisting of eight chapters, applies the principles of geography to investigate the interaction between modern military challenges, military forces and different aspects of geography. Important issues of regional and global security are related to globalisation and regional tensions that threaten to erupt into war. These tensions originate from differences that are based on religion, ethnicity, sub-nationality and prosperity.

Each chapter commences with an introduction that defines and constructs the central topic that is under examination. The body of the chapter is followed by a conclusion that summarises important details and lessons that could be learnt from the different case studies. The book concludes with an extensive glossary and short curriculum vitae of each of the authors. The terms in the glossary provide the reader with an easy reference, which is especially handy to readers who are new to the field of military geography. The text is well supported with maps, figures, graphs, tables and photographs that span the full length of the book. The fact that all photos and maps are in black and white deny the book of some contemporary appeal.

Modern Military Geography is written in uncomplicated, easy to read language. The book fully demonstrates the power of geography and the relevance of military geography in the modern world. The text tends to focus on the perspective of the United States military, but this does not necessarily deprive the book of international relevance, because of the universal nature of the underlying principles. This book is therefore recommended to a wide range of readers, which include military practitioners and military geographers and even laymen with an interest in the subject.

Jacques Bezuidenhout, Faculty of Military Science, University of Stellenbosch. 